\title{
Article
}

\section{The Temporal Pattern of Recovery in Eccentric Hamstring Strength Post- Soccer Specific Fatigue}

Rhodes, David, McNaughton, Lars and Greig, Matt

Available at http://clok.uclan.ac.uk/24217/

Rhodes, David ORCID: 0000-0002-4224-1959, MCNaughton, Lars and Greig, Matt (2019) The Temporal Pattern of Recovery in Eccentric Hamstring Strength Post-Soccer Specific Fatigue. Research in Sports Medicine, 27 (3). pp. 339-350. ISSN 1543-8627

It is advisable to refer to the publisher's version if you intend to cite from the work.

http://dx.doi.org/10.1080/15438627.2018.1523168

For more information about UCLan's research in this area go to http://www.uclan.ac.uk/researchgroups/ and search for <name of research Group>.

For information about Research generally at UCLan please go to http://www.uclan.ac.uk/research/

All outputs in CLoK are protected by Intellectual Property Rights law, including Copyright law. Copyright, IPR and Moral Rights for the works on this site are retained by the individual authors and/or other copyright owners. Terms and conditions for use of this material are defined in the policies page. 
The Temporal Pattern of Recovery in Eccentric Hamstring Strength Post-Soccer Specific Fatigue.

Dr David Mark Rhodes

Health Sciences

University of Central Lancashire

Brook Building

Fylde Road

Preston

PR1 2HE

Drhodes2@uclan.ac.uk

01772895490

Professor Lars McNaughton

Sport and Physical Activity

Edge Hill University

Ormskirk

England

Dr Matt Greig

Sport and Physical Activity

Edge Hill University

Ormskirk

England

Word Count: 2969

Keywords: fatigue, soccer, hamstring, injury, eccentric, strength 